\title{
Nitrogen Metabolism in West African Ghildren
}

\author{
BY BARBARA BRAY \\ Human Nutrition Research Unit, Medical Research Council Laboratories, \\ Holly Hill, London, N.W. 3 \\ (Received 20 November 195I)
}

Very few nitrogen-balance studies have been reported on human subjects whose diet is habitually on the margin between adequacy and starvation. Nitrogen balances have been determined in north China for children aged 4-5 (Kung \& Fang, 1935) and adolescent boys, aged I4-21 years (Kung \& Yeh, 1938). Adults have been used as subjects by Adolph \& Wang (1934) in China, and by Mitra, Verma \& Ahmed (1948) and Patwardhan, Mukundan, Rama Sastri \& Tulpule (1949) in India. All these experiments were made to compare the digestion and utilization of various staple cereals. The experiments described in this paper were performed in order to determine the nitrogen metabolism in African children and then, by comparison with American data (Macy, I942), to ascertain whether there is any difference in nitrogen economy between individuals accustomed to a poor and to a full diet.

\section{Subjects}

EXPERIMENTAL

Nitrogen-balance studies were made in the Gambia, British West Africa, on eight boys, aged 7-9 years, drawn from villages in the same district with the same general nutritional background. Details of the subjects are given in Table $\mathbf{r}$.

The Gambian dietary consists of a staple cereal with small amounts of meat and dried fish, and with groundnuts, beans, various green leaves and fruits in season. Eggs and milk are very uncommon and most of the population is without them altogether. The cereals, findi (Digitaria exilis), maize, rice, bulrush millet (Pennisetum spp.) and sorghum succeed each other as staples through the year. Findi, an early crop with grain the size of grass seed, is eaten soon after harvesting in July. Rice, the most popular staple, is eaten alone as long as the stocks last. When the rice is exhausted, some time in April, millet and sorghum, known collectively as 'coos', form the staple. In the preparation of these cereals, the chaff and much of the bran are removed by pounding in mortar. Rice is eaten whole but the other cereals are reduced to flour, the extraction rate of which varies from 70 to $85 \%$.

Signs usually associated with chronic malnutrition are very common in the Gambia, children are underweight and backward in physical development, and liver cirrhosis is frequently found. From September to October, there is usually a time of food shortage before the new crops are harvested. During this 'hungry season', adults lose weight and children tend to stop growing or may even lose weight. Infestation with malarial and filarial parasites and with Ascaris lumbricoides and Ankylostoma duodenale occurs and the demands created by these and other parasites constitute an additional strain on an already malnourished population.

The subjects all had intestinal parasites, the worm loads quoted are the average of three separate $24 \mathrm{l}$ egg counts. After the first two or three balances, the subjects 


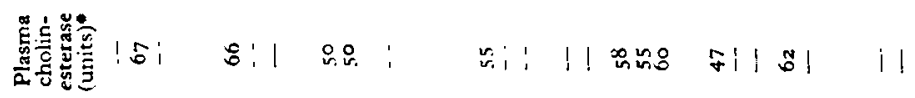

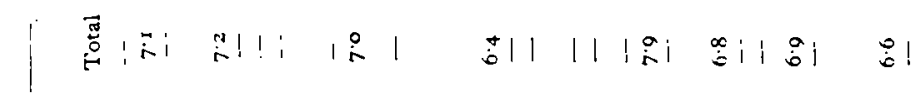

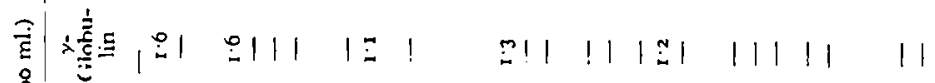

$\frac{8}{3}$

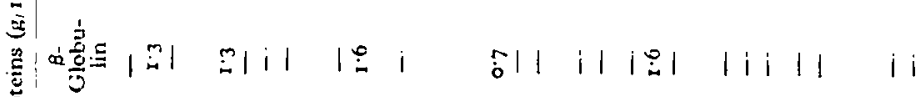

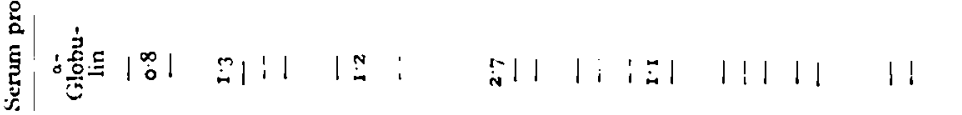

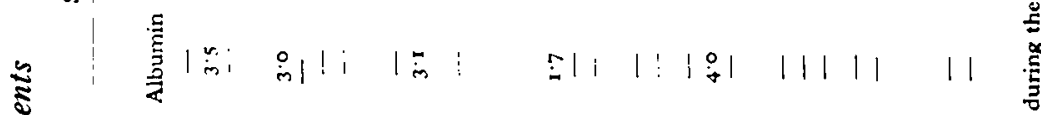

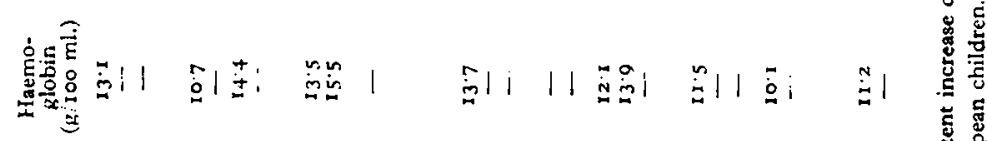

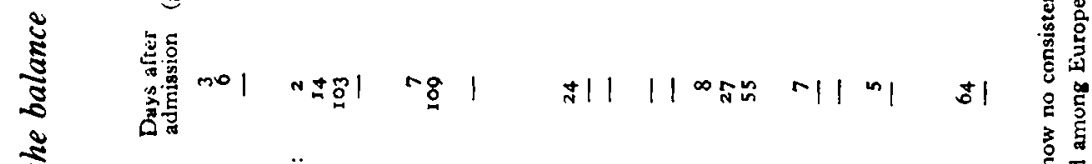

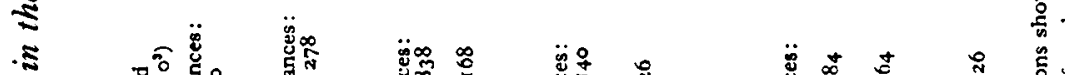

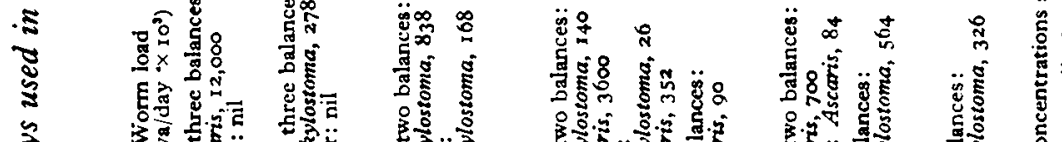

今े

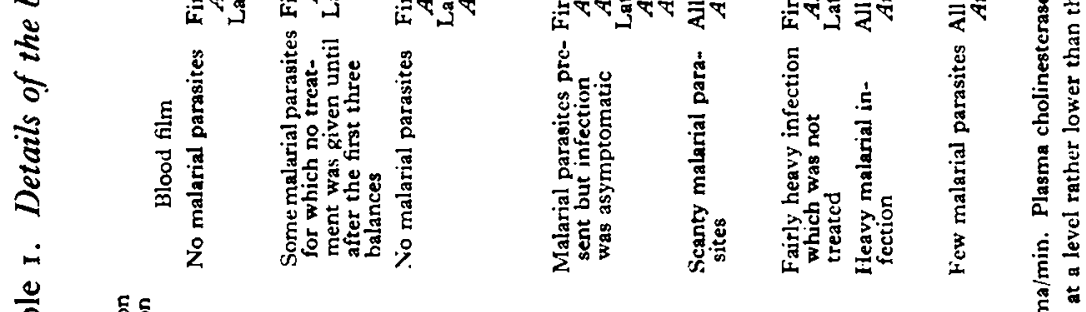

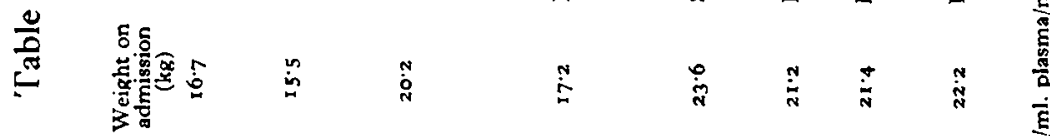

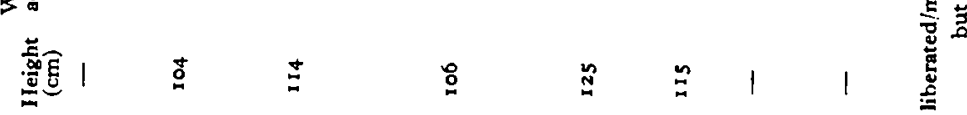

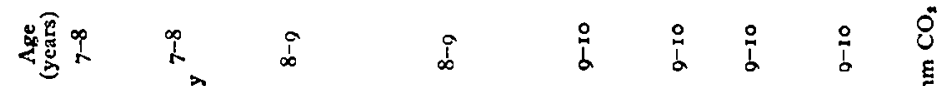

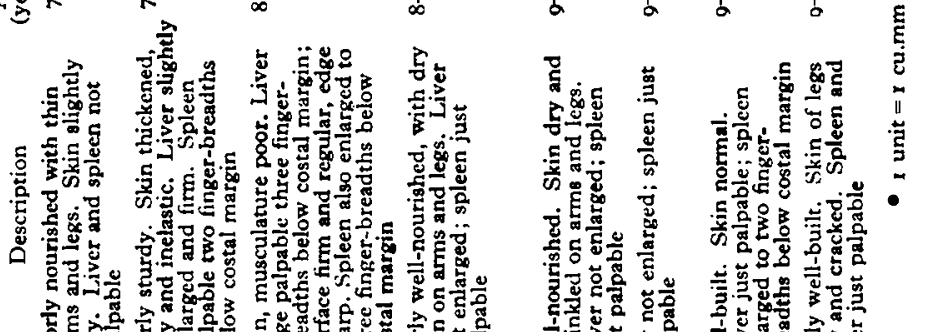
20.

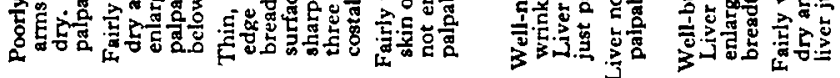

尊 
were dewormed with oil of chenopodium and tetrachlorethylene: no balances were done for a week after this treatment. No treatment for malarial parasites (Plasmodium falciparum) was given unless there were signs, such as fever.

Ages are estimated on Gambian standards of physical development, since ages over 2 years are not known with certainty. There were no signs of specific deficiency disease, but most cases showed changes in the skin, such as xerosis and 'crackling', which are commonly attributed to malnutrition (Platt, 1945).

\section{Examination of blood serum}

Serum proteins were fractionated by the method of Kibbrick \& Blonstein (1948) and the nitrogen of each fraction determined by the micro-Kjeldahl procedure, using the distillation apparatus described by Markham (1942). Protein fractions are quoted as $\mathrm{N} \times 6 \cdot 25$. Cholinesterase determinations were made by the Cartesian diver microgasometric method described by Waterlow (1950). Haemoglobin was estimated by the alkaline haematin method using a direct vision colorimeter and a standard solution of haematin.

\section{Liver biopsies}

Liver biopsies were done in seven of the subjects, the appearances of the samples are described below.

Case 1. One biopsy was done. There was slight cellular infiltration and fibrous thickening of the portal tracts, but no diffuse fibrosis. The hepatic cells appeared normal. There was no malarial pigment.

Case 2. Three biopsies were done and all showed essentially the same appearance. The portal tracts were infiltrated with lymphocytes. In one tract there were also cells resembling fibroblasts. The liver cells appeared normal. There were deposits of malarial pigment in portal tracts and Kupffer cells. Silver impregnation showed thickening of the fibrous tissue in portal tracts, with a few thick fibres growing out of the tracts into the parenchyma. There was a patchy increase in density of the perisinusoidal reticulin network. This liver might be regarded as an example of diffuse fibrosis at a very early stage probably arrested and inactive.

Case 3. Four biopsies were done. The first showed much cellular infiltration of the portal tracts with lymphocytes and cells resembling fibroblasts. The liver cells were normal. There was malarial pigment in portal tracts and Kupffer cells. Silver impregnation showed thick fibres growing out from the portal tracts into the parenchyma with some distortion of the normal architecture. In places there was an increase in the density of the reticulin network around the sinusoid. In the later biopsies the degree of fibrosis seemed to be progressively less. In the fourth biopsy there was only slight cellular infiltration of the portal tracts. Some abnormally thick fibres were visible extending from the tracts into the lobules, but they were fewer than before. The architecture was normal.

Case 4. One biopsy was done. 'The liver was nearly normal. There was slight cellular infiltration of the portal tracts and a little malarial pigment in tracts and Kupffer cells. There was no fibrosis. 
Case 5. One biopsy was done. The liver was normal except for slight cellular infiltration of the portal tracts and a small amount of malarial pigment.

Case 6. No liver biopsy done.

Case 7. One biopsy was done. There was moderate cellular infiltration of the portal tract with malarial pigment in tracts and Kupffer cells. The liver cells were normal. There was some outgrowth of the thick fibres from the edges of the portal tract and in some areas the density of the perisinusoidal reticulin network was increased.

Case 8. One biopsy was done. There was, as in all the other cases, cellular infiltration of the portal tracts. The liver cells were normal. There was little malarial pigment in the Kupffer cells. A few abnormally thick fibres extended from the edges of the portal tract into the parenchyma. This liver, like that of the preceding case, showed an increase of connective tissues that was just beyond the normal limits.

\section{Supervision during balance tests}

Three-day balances were done on two subjects at one time. During the balance, the boys remained ambulant and were allowed to play freely under the supervision of a ward orderly from $7.00 \mathrm{a} . \mathrm{m}$. to $7.00 \mathrm{p} . \mathrm{m}$. The feeding and the conduct of the balances were under experienced supervision.

The diet had previously been shown to satisfy appetite and the amounts eaten varied from subject to subject. The morning meal, taken at 7.30 a.m., was about $200 \mathrm{~g}$ of a porridge made of millet or sorghum with the addition of some sugar. The midday meal consisted of steamed rice (about $200 \mathrm{~g}$ ) and minced meat (about $5^{\circ} \mathrm{g}$ ) with highly seasoned gravy. In the afternoon, the subjects were given about $5^{\circ} \mathrm{g}$ of orange, pawpaw or banana. The evening meal, given at 6.30 p.m. was again $200 \mathrm{~g}$ rice with $50 \mathrm{~g}$ meat and gravy. This diet, which will be referred to as the 'ward diet' was undoubtedly an improvement on the diets that the subjects would have received before admission: the proportion of animal protein was higher and the cereals mixed. As Mitra et al. (1948) and Adolph \& Chang (1935) have shown, cereal proteins have higher values when mixed than when any one cereal forms the staple.

Body-weights were recorded daily during the balances and twice weekly between balances. The boys were weighed immediately before the midday meal. Bodyweights on the first day of each balance period are given in Table 4 .

\section{Collection and treatment of specimens}

(a) Diet. Since the foods supplied were fairly homogeneous, they were sampled by taking one-tenth of the quantity of each foodstuff eaten. The samples collected during the 3-day period were stored in a glass jar with the addition of a little chloroform until the balance was completed when they were quantitatively transferred to a blender with $100 \mathrm{ml}$. water. Two $15 \mathrm{~g}$ portions of the homogenized sample were weighed into stoppered bottles, treated with $15 \mathrm{ml}$. concentrated $\mathrm{H}_{2} \mathrm{SO}_{4}$ and left for 2 or 3 days. At the end of this time, water was added to the charred samples. When cool, the liquid was transferred to a $100 \mathrm{ml}$. flask and made up to volume with washings. After thorough agitation, two $5 \mathrm{ml}$. portions were pipetted into Kjeldahl flasks and 
incinerated with $2 \mathrm{ml}$. concentrated $\mathrm{H}_{2} \mathrm{SO}_{4}$ and about $0.2 \mathrm{~g}$ catalyst mixture $\left(\mathrm{K}_{2} \mathrm{SO}_{4}\right.$, I6o g; $\mathrm{CuSO}_{4} .5 \mathrm{H}_{2} \mathrm{O}, 40 \mathrm{~g} ; \mathrm{Na}_{2} \mathrm{SeO}_{4}, 0.68 \mathrm{~g}$ ). Incineration was continued for at least $45 \mathrm{~min}$ after clearing. Nitrogen was estimated by the micro-Kjeldahl method, using Markham's apparatus (Markham, I942).

(b) Faeces. Each balance started at 12.00 noon with the feeding of a carmine marker before the midday meal and collection of stools was started with the first appearance of carmine. A second marker was given before the midday meal 3 days later and collection of stools was discontinued with the appearance of the second marker, the marked stool being discarded. Faeces were stored in weighed glass jars under $0.1 \mathrm{~N}-\mathrm{HCl}$, each stool being mixed with the acid when it was added to the jar. When the collection was complete, the jar was reweighed and the contents thoroughly mixed with a glass rod. Duplicate portions of about $20 \mathrm{~g}$ were weighed into bottles and $20 \mathrm{ml}$. concentrated $\mathrm{H}_{2} \mathrm{SO}_{4}$ added. The bottles were then stoppered and left for 4 or 5 days. When charring was complete, water was added and the samples treated in the same way as the diet specimens.

(c) Urine. The subjects emptied their bladders at 12.00 noon on the Ist day of the balance. 24-h collections were made in bottles containing $5 \mathrm{ml}$. concentrated $\mathrm{HCl}$. At the end of each $24 \mathrm{~h}$ the volume of urine was measured and one-tenth stored in the refrigerator. At the end of the balance, duplicate $1 \mathrm{ml}$. portions of the mixed sample were taken for analysis. Urea was estimated by the method of Cole (193 I) and ammonia by Conway's (r 940 ) method.

\section{RESULTS}

Diet. The composition of the diet is given in Table 2, values are calculated from nitrogen analyses and food tables. Throughout this paper, comparison with American children is restricted to the results given by Macy ( 1942 ). Since no values for 7-yearold children are quoted in that work, the values for 6-year-old children have been taken for purposes of comparison.

Table 2. Average daily intake of protein, fat, carbohydrate and calories by a West African boy during balance experiments

\begin{tabular}{|c|c|c|c|c|}
\hline & $\begin{array}{l}\text { Protein } \\
\text { (g) }\end{array}$ & $\begin{array}{l}\text { Fat } \\
(\mathrm{g})\end{array}$ & $\begin{array}{c}\text { Available } \\
\text { carbohydrate } \\
\text { (as glucose) } \\
\text { (g) }\end{array}$ & $\begin{array}{l}\text { Calories } \\
\text { (Cal.) }\end{array}$ \\
\hline \multicolumn{5}{|l|}{ Cereals: } \\
\hline Rice & I3 & 2 & 169 & 770 \\
\hline 'Coos'* & 3 & - & 15 & 70 \\
\hline Meat & 36 & 9 & - & 240 \\
\hline Other foodstuffs: & & & & \\
\hline Fruit & - & - & 5 & 20 \\
\hline Sugar in 'coos' porridge & - & - & 8 & 30 \\
\hline Groundnut oil in gravy & - & 20 & 一 & 180 \\
\hline Total & $5^{2}$ & 31 & 197 & 1310 \\
\hline
\end{tabular}

Macy's children of the same age groups were receiving 1900-2500 Cal. and 64-82 g protein. The body-weights of the American children were, however, much higher 
than those of the African children of similar age, and when intake was expressed on a body-weight basis, the discrepancy was removed as shown in Table 3 .

Table 3. Comparison of the protein intake of West African boys in balance experiments with that of American children (Macy, 1942)

\begin{tabular}{|c|c|c|c|c|}
\hline \multirow{3}{*}{$\begin{array}{c}\text { Age } \\
\text { (years) }\end{array}$} & \multicolumn{4}{|c|}{ Protein intake } \\
\hline & \multicolumn{2}{|c|}{ (g/day) } & \multicolumn{2}{|c|}{ (g/kg body-weight/day) } \\
\hline & African & American & African & American \\
\hline 6 & - & 64 & - & $2 \cdot 9$ \\
\hline 7 & 49 & - & 3.0 & - \\
\hline $\begin{array}{l}8 \\
9\end{array}$ & $52 \cdot 5$ & 74 & $2 \cdot 8$ & $\begin{array}{r}2 \cdot 8 \\
2 \cdot 8\end{array}$ \\
\hline 9 & 53 & 82 & $2 \cdot 4$ & $2 \cdot 8$ \\
\hline
\end{tabular}

The results of the balances are given in 'Table 4 .

Table 4. Results of 3-day nitrogen balances on eight West African boys, aged 7-9 years, on a mixed diet

\begin{tabular}{|c|c|c|c|c|c|c|c|c|c|}
\hline \multirow{2}{*}{$\begin{array}{l}\text { Case } \\
\text { no. }\end{array}$} & \multirow{2}{*}{$\begin{array}{c}\text { Age } \\
\text { (years) }\end{array}$} & \multirow{2}{*}{$\begin{array}{c}\text { Beginning of } \\
\text { balance (days } \\
\text { after admission) }\end{array}$} & \multirow{2}{*}{$\begin{array}{c}\text { Weight } \\
(\mathrm{kg})\end{array}$} & \multicolumn{4}{|c|}{ Nitrogen (g/day) } & \multirow{2}{*}{$\begin{array}{l}\text { Liver biopsy } \\
\text { (degree of } \\
\text { fibrosis) }\end{array}$} & \multirow{2}{*}{$\begin{array}{l}\text { Enlarge- } \\
\text { ment of } \\
\text { liver }\end{array}$} \\
\hline & & & & Intake & Faecal & Urinary & Balance & & \\
\hline \multirow[t]{5}{*}{1} & \multirow[t]{5}{*}{7} & II & 16.7 & $8 \cdot 1$ & $1 \cdot 5$ & $3 \cdot 6$ & $3 \cdot 0$ & & \\
\hline & & 14 & $16 \cdot 5$ & $7 \cdot 2$ & $1 \cdot 5$ & $3 \cdot 2$ & $2 \cdot 5$ & & \\
\hline & & 27 & $16 \cdot 7$ & $7 \cdot 1$ & 0.9 & $4^{\circ} 0$ & $2 \cdot 2$ & $\circ$ & $\circ$ \\
\hline & & 49 & $16 \cdot 7$ & $9 \cdot 0$ & $I \cdot 5$ & $6 \cdot 5$ & $1 \cdot 0$ & & \\
\hline & & 53 & 16.7 & $8 \cdot 0$ & $1 \cdot 2$ & $6 \cdot 0$ & 0.8 & & \\
\hline \multirow[t]{6}{*}{2} & \multirow[t]{6}{*}{7} & 3 & 15.5 & $6 \cdot 5$ & 0.8 & $4 \cdot 3$ & $\mathrm{I} \cdot 4$ & & \\
\hline & & 6 & 15.5 & $7 \cdot 1$ & $I \cdot I$ & $6 \cdot 0$ & 0.0 & & \\
\hline & & 31 & 15.7 & $8 \cdot 5$ & $1 \cdot 4$ & $4 \cdot 0$ & $3 \cdot I$ & Early & + \\
\hline & & 62 & 15.5 & $7 \cdot 5$ & $1 \cdot 0$ & $5 \cdot 5$ & $\mathbf{I} \cdot \mathbf{0}$ & + & \\
\hline & & 67 & 15.5 & 8.9 & $2 \cdot 0$ & $6 \cdot 2$ & 0.7 & & \\
\hline & & 117 & 16.5 & $7 \cdot 8$ & $1 \cdot 0$ & $4 \cdot 8$ & $2 \cdot 0$ & & \\
\hline \multirow[t]{6}{*}{3} & \multirow[t]{6}{*}{8} & 40 & $20 \cdot 2$ & $8 \cdot 1$ & $I \cdot 6$ & $4 \cdot 5$ & $2 \cdot 0$ & & \\
\hline & & 43 & 20.0 & $7 \cdot 2$ & $1 \cdot 3$ & $6 \cdot 2$ & -0.3 & & \\
\hline & & 57 & 19.5 & $7 \cdot 1$ & $\mathrm{I} \cdot \mathbf{2}$ & $5 \cdot 8$ & 0.1 & $+t$ & +++ \\
\hline & & 75 & 19.5 & $9 \cdot 0$ & $I \cdot 2$ & $7 \cdot 7$ & $0 \cdot 1$ & Improving & \\
\hline & & 78 & $19 \cdot 5$ & $8 \cdot 0$ & 0.6 & $7 \cdot 8$ & -0.4 & & \\
\hline & & $I_{13}$ & 20.5 & $7 \cdot 8$ & $1 \cdot 0$ & $6 \cdot 1$ & 0.7 & & \\
\hline \multirow[t]{3}{*}{4} & \multirow[t]{3}{*}{8} & 7 & $17 \cdot 2$ & 8.9 & $I \cdot 5$ & $6 \cdot 3$ & $I \cdot I$ & & \\
\hline & & 14 & $17 \cdot 4$ & $9 \cdot 0$ & $I \cdot 2$ & 6.4 & $I \cdot 4$ & o & 0 \\
\hline & & 67 & $18 \cdot 2$ & $8 \cdot 8$ & $I \cdot O$ & 4.5 & $3 \cdot 3$ & & \\
\hline \multirow[t]{4}{*}{5} & \multirow[t]{4}{*}{9} & 12 & $23 \cdot 6$ & $9 \cdot 0$ & $1 \cdot 4$ & $7 \cdot 2$ & 0.4 & & \\
\hline & & 28 & $23 \cdot 6$ & $8 \cdot 1$ & 0.8 & $8 \cdot 3$ & $-I \cdot 0$ & ० & 0 \\
\hline & & 48 & $24^{\circ} 1$ & $9 \cdot 0$ & 0.4 & $6 \cdot 9$ & I'7 & & \\
\hline & & 62 & $24 \cdot 1$ & $8 \cdot 7$ & 0.9 & $8 \cdot 4$ & -0.6 & & \\
\hline \multirow[t]{3}{*}{6} & \multirow[t]{3}{*}{9} & 9 & $2 x \cdot 2$ & $8 \cdot 1$ & $1 \cdot 5$ & $4 \cdot 8$ & $\mathrm{I} \cdot 8$ & & \\
\hline & & 16 & $2 I \cdot 2$ & $8 \cdot 8$ & $1 \cdot 3$ & $4 \cdot 8$ & $2 \cdot 7$ & - & 0 \\
\hline & & 48 & $22 \cdot 0$ & $8 \cdot 8$ & $1 \cdot 0$ & $6 \cdot 5$ & $\mathrm{I} \cdot 3$ & & \\
\hline \multirow[t]{4}{*}{7} & \multirow[t]{4}{*}{9} & 3 & $2 \mathrm{I} \cdot 4$ & $7 \cdot 4$ & 0.7 & $5 \cdot 8$ & 0.9 & & \\
\hline & & 33 & $21 \cdot 7$ & $8 \cdot 4$ & 0.6 & 47 & $3 \cdot 1$ & & \\
\hline & & 63 & $22 \cdot 9$ & $8 \cdot 9$ & 0.6 & $6 \cdot 0$ & $2 \cdot 3$ & + & ++ \\
\hline & & 84 & $22 \cdot 2$ & $8 \cdot 4$ & 0.8 & $5 \cdot 7$ & $I \cdot 9$ & & \\
\hline \multirow[t]{4}{*}{8} & \multirow[t]{4}{*}{9} & 3 & $22 \cdot 2$ & $7 \cdot 4$ & $1 \cdot 4$ & 5.9 & 0.1 & & \\
\hline & & 33 & $22 \cdot 2$ & $8 \cdot 4$ & 0.5 & $3 \cdot 2$ & 47 & & \\
\hline & & 63 & $22 \cdot 4$ & $8 \cdot 9$ & 0.2 & $2 \cdot 9$ & $5 \cdot 8$ & + & + \\
\hline & & 84 & $21 \cdot 7$ & $8 \cdot 4$ & $1 \cdot 0$ & 5.0 & 2.4 & & \\
\hline
\end{tabular}


Parasitic infestation. Infestation with Ascaris lumbricoides and Ankylostoma duodenale is endemic in the Gambia. Little is known of the demand created by these parasites for nutrients other than iron. In these experiments it was important to know whether the parasites affected the utilization of dietary protein. If they did, another variable would be introduced to affect comparisons between individuals and with data from other countries. Intestinal parasites might increase their host's requirements of protein by appropriation of dietary amino-acids for their own growth and production of eggs, or by causing tissue damage and haemorrhage, or by stimulating the production of antibodies. These effects may pass unobserved when dietary protein is ample, but when protein is limited they may impose a perceptible strain upon the host. The strain may be exaggerated by a demand upon a specific amino-acid that is scarce, e.g. lysine, which is low in a cereal diet and which is essential for the synthesis of the host's own protein. Balances carried out before and after elimination of parasites, however, showed no consistent differences in the absorption or utilization of dietary protein indicating that the effect of these parasites on the host's nitrogen metabolism is so slight as to be masked by the variation between balances. The losses of nitrogen in the urine and faeces of African children are compared with those for American children in Table 5 .

Table 5. Comparison of the excretion of nitrogen in African and American* children

\begin{tabular}{|c|c|c|c|c|c|c|}
\hline \multirow{3}{*}{$\begin{array}{c}\text { Age } \\
\text { (years) }\end{array}$} & \multicolumn{4}{|c|}{ Urinary nitrogen $(\mathrm{g} / 24 \mathrm{~h})$} & \multicolumn{2}{|c|}{$\begin{array}{c}\text { Faecal nitrogen } \\
\text { (as percentage of intake) }\end{array}$} \\
\hline & \multicolumn{2}{|c|}{ African children } & \multicolumn{2}{|c|}{ American children } & & \\
\hline & Mean & S.D. & Mean & S.D. & children & $\begin{array}{l}\text { children } \\
\text { cherican }\end{array}$ \\
\hline 6 & - & - & $8 \cdot 65$ & 0.56 & - & - \\
\hline 7 & $4 \cdot 9$ & $I \cdot 17$ & - & -1 & - & - \\
\hline 8 & $6 \cdot 1$ & I.05 & $9 \cdot 81$ & $I \cdot 45\}$ & $13 \cdot 3$ & 10.3 \\
\hline 9 & $5 \cdot 7$ & $1 \cdot 63$ & $\begin{array}{l}\text { ro.62 } \\
\text { Macy }\end{array}$ & 0.301 & S.D. $4^{-8}$ & S.D. 2.0 \\
\hline
\end{tabular}

Faecal nitrogen. The faecal nitrogen results for the African subjects are grouped together beside the results for the American 6- to 9-year-old children since Macy's experiments showed that faecal nitrogen is constantly about $10 \%$ of the intake in all age groups. The comparison shows that the proportion of dietary nitrogen not absorbed was significantly higher in these African children than in their American counterparts $(P<0.05)$. A high output of faecal nitrogen is frequently reported in publications from India and China. Kung \& Yeh (1938) found values of 37 and $31 \%$ of the nitrogen intake. Patwardhan et al. (1949), using adults accustomed to a vegetarian diet, found an average faecal nitrogen of $17 \%$ of the intake. This high value remained constant when the cereal protein was replaced by animal protein to the extent of 25 and $50 \%$, showing that it was not related to the nature of the dietary protein. A high faecal nitrogen may be due to a high 'metabolic' nitrogen (nitrogen of non-dietary origin). The 'metabolic' nitrogen of Indian subjects has been shown to be about $\mathrm{I} \cdot 0 \mathrm{~g}$ /day (Patwardhan, Sreenivasan \& Karembelkar, unpublished data quoted by Patwardhan et al. 1949; Basu \& Basak, 1939) whereas that 
of American subjects is $0.4 \mathrm{~g} /$ day (Hegsted, Tsongas, Abbott \& Stare, 1946). The metabolic nitrogen was not determined in the present experiments but a similar increase in the metabolic nitrogen of the African boys would account for part of the relatively high faecal nitrogen. Other reasons for a high proportion of a faecal nitrogen may be faulty digestion or absorption of dietary protein, the presence of indigestible protein (Mitchell \& Beadles, 1937), of fibrous material (Whitacre, Willard \& Blunt, 1929-30) or of a great bulk of carbohydrate material that would encourage the growth of bacteria. Whatever may be the cause of a high faecal nitrogen, its effect is to reduce the available nitrogen in a diet already low in protein.

Table 6. Relation between the total urinary nitrogen and the excretion of urea and ammonia

\begin{tabular}{lrcc}
\multicolumn{1}{c}{ Subjects } & Total & Urea & Ammonia \\
European adults & $16 \cdot 0$ & $14 \cdot 0$ & 0.56 \\
Hongkong students & $14 \cdot 8$ & $11 \cdot 8$ & 0.67 \\
Manchurian students & $11 \cdot 1$ & $8 \cdot 4$ & 0.69 \\
Peking students & $9 \cdot 9$ & $8 \cdot 1$ & 0.76 \\
Peking skilled labourers & $9 \cdot 1$ & $7 \cdot 1$ & 0.76 \\
Peking poor adults & $7 \cdot 1$ & $4 \cdot 0$ & - \\
Bengal middle class adults & $4 \cdot 8$ & $2 \cdot 0$ & - \\
American children (9 years) & 10.6 & $9 \cdot 1$ & 0.36 \\
Undernourished American & $5 \cdot 1$ & - & 0.26 \\
$\quad$ children & & & \\
African children & 5.9 & 4.5 & 0.60
\end{tabular}

$\quad$ Reference
Cole (1928)
Wong (1928)
Wang (1936)
Read \& Wong (1923)
Read \& Wong (1923)
Read \& Wong (1923)
Ray \& Ganguly (1938)
Macy (1942)
Wang \& Kaucher (1929)
$\quad$

Urinary nitrogen. Analyses of urine during balance periods showed low total nitrogen values compared with Macy's results. Although the excretion of urea was also below the average American value, that of ammonia was higher. Similar results are found in papers from India and China. These results are collected together in Table 6. Gamble, Ross \& Tisdall (1923) have shown that in acutely fasting individuals urinary ammonia is high, replacing fixed bases in the neutralization of increased quantities of acids. Table 6 shows that, among adults, the excretion of ammonia nitrogen rises as the excretion of total nitrogen and urea becomes less, suggesting that a similar adjustment may occur in individuals who are chronically malnourished. The series of results from children is shorter and is inconsistent. More results from children are necessary before the significance of this relationship can be assessed.

Absorbed nitrogen. The utilization of absorbed nitrogen is reflected by the final balance figure. These results are summarized in Table 7. In spite of the high faecal losses, retentions on the whole were much higher than those obtained in Macy's balances on American children. When a fasted child is given an adequate diet, nitrogen retention will be very marked, becoming less as arrears are made good (Wang, Hawks \& Hays, 1928). In these boys there were no symptoms of acute starvation. Their muscles were not strikingly wasted, neither were they listless or apathetic. By American standards, their nitrogen intake must have been low before 
admission to result in underdevelopment. After improvement of diet on admission, nitrogen retentions exceeded the normal American values. Patwardhan et al. (1949), however, found that the nitrogen retention in Indian adults was not increased when the quality of the dietary protein was improved. The contrast with Patwardhan's observations suggests that the growing individual may be able to take advantage of an improvement in dietary protein whereas the adult is not able to do so.

\section{Table 7. Comparison of the retention of nitrogen in African and American*}

\begin{tabular}{|c|c|c|c|c|c|}
\hline \multirow[b]{2}{*}{$\begin{array}{c}\text { Age } \\
\text { (years) }\end{array}$} & \multirow[b]{2}{*}{$\begin{array}{c}\text { Case } \\
\text { no. }\end{array}$} & \multicolumn{2}{|c|}{ Nitrogen retention $(g / 24 \mathrm{~h})$} & \multicolumn{2}{|c|}{$\begin{array}{l}\text { Nitrogen retention } \\
\text { (as percentage of intake) }\end{array}$} \\
\hline & & $\begin{array}{l}\text { African } \\
\text { children }\end{array}$ & $\begin{array}{l}\text { American } \\
\text { children }\end{array}$ & $\begin{array}{l}\text { African } \\
\text { children }\end{array}$ & $\begin{array}{l}\text { American } \\
\text { children }\end{array}$ \\
\hline 6 & - & - & 0.46 & - & 5 \\
\hline 7 & $\begin{array}{l}\mathbf{I} \\
\mathbf{2}\end{array}$ & $\begin{array}{l}1 \cdot 9 \\
1 \cdot 4\end{array}$ & - & $\begin{array}{l}24 \\
18\end{array}$ & - \\
\hline 8 & $\begin{array}{l}3 \\
4\end{array}$ & $\begin{array}{l}0 \cdot 4 \\
1 \cdot 9\end{array}$ & $\stackrel{0.62}{-}$ & $\begin{array}{r}5 \\
22\end{array}$ & 5 \\
\hline 9 & $\begin{array}{l}5 \\
6 \\
7 \\
8\end{array}$ & $\begin{array}{l}0.1 \\
1.9 \\
2.1 \\
3.3\end{array}$ & $\begin{array}{c}1.05 \\
- \\
-\end{array}$ & $\begin{array}{r}1 \\
22 \\
25 \\
39\end{array}$ & $\begin{array}{l}8 \\
- \\
- \\
-\end{array}$ \\
\hline
\end{tabular}

Niirogen retention and body-weight. The retention of nitrogen by these children does not appear to be related to increases in body-weight in the usual way. Nitrogen retentions of this order should result in gains of $I-2 \mathrm{~kg}$ in a month, but the weights recorded in Table 4 show no such increase although there was no doubt that the children were receiving a diet that was quite good by their home standards. This discrepancy suggests either that the retention of nitrogen during the days of balancestudies was greater than at other times in the period of the whole observation, or that changes were taking place that were not shown up by nitrogen balances. It does not seem probable that the first explanation could account for the whole of the striking degree of nitrogen retention observed but no evidence can yet be presented to support the alternative possibility, that a gain in true body-weight was accompanied by a loss of fluid.

\section{DISCUSSION}

The factors affecting the metabolism of protein are extremely complex. Different stages of growth create different demands and chronological age, even if accurate, may not be an index of physiological age. Dean Smith (personal communication) has shown that the ossification of cartilages, ages of eruption of teeth and onset of puberty are all delayed in Gambian children. Such considerations make it difficult to assess the significance of comparisons between individuals and between children of different populations; it may be said, however, that the results presented here suggest that these African boys, retarded in physical development, seem to be 
conditioned to a plane of nitrogen metabolism lower than that of American children of the same age, with smaller intakes satisfying smaller requirements.

Previous nitrogen-balance studies have not covered quite the same ground. Some have described the nitrogen metabolism of fasting men, and others that of adults and children recovering from acute starvation. The subjects of the experiments described here, however, were children who had not been deprived of their normal food but were drawn at random from a population conditioned to chronic malnourishment. Balance studies from India and China, where dietary conditions are similar to those of West Africa, have been nearly all confined to adults and only in America have children been the subjects of detailed reports (White House Conference on Child Health and Protection, 1932; Maroney \& Johnston, I937; Macy, I942). These smallscale cxperiments present data on the nitrogen economy of the human body during growth at levels of protein and calorie intake which are habitually below the American standards.

\section{SLMMARY}

1. A series of nitrogen balances was carried out in the Gambia on eight West African boys, aged 7-9 years.

2. No consistent change in the balance of nitrogen metabolism was found after the elimination of the parasites Ascaris lumbricoides and Ankylostoma duodenale.

3. The proportion of dietary nitrogen lost in the faeces was higher than in American children of similar chronological age.

4. 'The total urinary nitrogen was low compared with that of American children, with a lower proportion of urea and a higher proportion of ammonia.

5. The reduced urinary nitrogen resulted in a larger retention on a smaller intake than in American children.

6. Balance data confirmed clinical observations on retarded development. The reduced requirements of chronically malnourished Gambian children were satisfied by intakes smaller than those of American children of the same age.

7. Retention of nitrogen was not accompanied by a corresponding increase in body-weight under the conditions of this test. At present there is no explanation of this observation.

'Ihanks are due to Professor B. S. Platt for his interest and criticism throughout this work, to Dr J. C. Waterlow for his help and for details of liver biopsies and the cholinesterase determinations; also to the nursing staff of the Medical Research Council's Field Research Station, Fajara, the Gambia, for their willing co-operation and to Miss J. Fenning for her help in the preparation of the manuscript.

\section{REFERENCES}

Adolph, W. H. \& Chang, F.-W. (1935). Chin. J. Physiol. 9, 245.

Adolph, W. H. \& Wang, T.-C. (1934). Chin. med. F. 48, 59.

Basu, K. P. \& Basak, M. N. (1939). Indian Y. med. Res. 27, 115.

Cole, S. W. (1928). Practical Physiological Chemistry, 8th ed., p. 282. Cambridge: W. Heffer and Sons. Cole, S. W. (1931). Biochem. F. 25, 1653.

Conway, E. J. (I940). Microdiffusion Analysis and Volumetric Error. New York: Van Nostrand Co.

Gamble, J. L., Ross, G. S. \& Tisdall, F. F. (1923). F. biol. Chem. 57, 633. 
Hegsted, D. M., Tsongas, A. G., Abbott, D. B. \& Stare, F. J. (1946). F. Lab. clin. Med. 31, 261.

Kibbrick, A. C. \& Blonstein, M. (1948). F. biol. Chem. 176, 983 .

Kung, L.-C. \& Fang, W.-Y. (1935). Chin. F. Physiol. 9, 375.

Kung, L.-C. \& Yeh, H.-L. (1938). Chin. F. Physiol. 13, 285.

Macy, I. G. (1942). Nutrition and Chemical Growth in Childhood, vol. I. Springfield, Ill.: C. C. 'Thomas.

Markham, R. (1942). Biochem. Y. 36, 790.

Maroney, J. W. \& Johnston, J. A. (1937). Amer. F. Dis. Child. 54, 29.

Mitchell, H. H. \& Beadles, J. R. (1937). F. Nutr. 14, 597.

Mitra, K., Verma, S. K. \& Ahmed, S. (1948). Indian F. med. Res. 36, 26 I.

Patwardhan, V. N., Mukundan, R., Rama Sastri, B. V. \& Tulpule, P. G. (1949). Indian Y. med. Res. 37, 327.

Platt, B. S. (1945). Brit. med. Bull. 3, 179.

Ray, S. N. \& Ganguly, R. (1 938). Indian F. med. Res. 26, 459.

Read, B. E. \& Wong, S. Y. (1923). Philipp. Y. Sci. 22, 127.

Wang, C. F. (1936). Chin. F. Physiol. 10, 135.

Wang, C. C., Hawks, J. E. \& Hays, B. B. (1928). Amer. F. Dis. Child. 35, 968.

Wang, C. C. \& Kaucher, M. (1929). Amer. F. Dis. Child. 38, 468.

Waterlow, J. (1950). Lancet, 258, 908.

Whitacre, J., Willard, A. \& Blunt, K. (1929-30). F. Nutr. 2, I87.

White House Conference on Child Health and Protection (1932). Growth and Development of the Child: $I I I$, Nutrition. New York: Century Co.

Wong, S. Y. (1928). Chin. F. Physiol. Rep. Ser. 1, 123.

\title{
The Effect of Fruit-syrup Supplements on the Assimilation of Food from the Alimentary Canal
}

\section{Their Effect on the Digestion of Milk in the Stomachs of Young Rats}

\author{
By H. T. FAWNS AND G. H. BOURNE \\ Departments of Biochemistry and Histology, London Hospital Medical College, \\ Turner Street, London, E. I
}

(Rectived 14 December 195I)

The increasing consumption in recent years of fruit juices and syrups manufactured from them makes it a matter of some importance to investigate their effect on the digestion and assimilation of other foodstuffs taken concurrently. This applies rather particularly to milk, with which such syrups and juices are often mixed. Here the two matters of chief interest are, first, the effect of fruit juices on the consistency of the clot and its speed of breakdown, and secondly, their effect on the secretion of gastric juice. Fruit juices and their products contain considerable amounts of titratable organic acids, which might be sufficient to alter the $\mathrm{pH}$ of the stomach contents and have a significant effect on both these factors.

Earlier investigations appear to have been carried out chiefly on mixtures of milk with fresh orange juice or lemon juice. Thus, Barenberg, Abramson \& Messer (1930), in reporting their clinical experience over 5 years, during which 145 infants received a mixture of lemon juice and milk for 6-12 months, claimed that these infants grew better than those receiving milk alone, and that the incidence of diarrhoea was reduced. Woodward (1930) reported similar favourable results with orange juice and milk in infant feeding. One ounce strained orange juice was added to $16 \mathrm{oz}$. milk. 